\title{
GEOTHERMAL ENERGY FOR THE BENEFIT OF THE PEOPLE
}

\author{
by Ingvar B. FRIDLEIFSSON
}

\begin{abstract}
Geothermal energy for electricity generation has been produced commercially since 1913, and for four decades on the scale of hundreds of MW both for electricity generation and direct use. The utilisation has increased rapidly during the last three decades. In 2000, geothermal resources have been identified in over 80 countries and there are quantified records of geothermal utilisation in 58 countries in the world. The worldwide use of geothermal energy amounts to $49 \mathrm{TWh} / \mathrm{a}$ of electricity and $53 \mathrm{TWh} / \mathrm{a}$ for direct use. Electricity is produced with geothermal steam in 21 countries spread over all continents. Five countries obtain $10-22 \%$ of their electricity from geothermal. Only a small fraction of the geothermal potential has been developed so far, and there is ample space for an accelerated use of geothermal energy both for electricity generation and direct applications. A comparison of the renewable energy sources (data from the UN World Energy Assessment Report) shows the current electrical energy cost to be 2-10 US $\$ / \mathrm{kWh}$ for geothermal and hydro, 5-13 US $\$ / \mathrm{kWh}$ for wind, 5-15 US $\$ / \mathrm{kWh}$ for biomass, 25-125 US $\$ / \mathrm{kWh}$ for solar photovoltaic and 12-18 US $\$ / \mathrm{kWh}$ for solar thermal electricity. Of the total electricity production from renewables of $2826 \mathrm{TWh}$ in $1998,92 \%$ came from hydropower, 5.5\% from biomass, 1.6\% from geothermal and $0.6 \%$ from wind. Solar electricity contributed $0.05 \%$ and tidal $0.02 \%$. Comparing four "new" renewable energy sources (geothermal, wind, solar and tidal), shows $70 \%$ of the electricity generated by the four to come from geothermal with only $42 \%$ of the total installed capacity. Wind energy contributes $27 \%$ of the electricity, but has $52 \%$ of the installed capacity. Solar energy produces $2 \%$ of the electricity and tidal energy $1 \%$. Biomass constitutes $93 \%$ of the total direct heat production from renewables, geothermal $5 \%$, and solar heating $2 \%$. Heat production from renewables is commercially competitive with conventional energy sources. The current cost of direct heat from biomass is 1-5 US $\$ / \mathrm{kWh}$, geothermal 0.5-5 US $\$ / \mathrm{kWh}$, and solar heating 3-20 US $\$ / \mathrm{kWh}$. Geothermal energy, with its proven technology and abundant resources, can make a significant contribution towards reducing the emission of greenhouse gases.
\end{abstract}

\section{INTRODUCTION}

At the turn of the millennium, two billion people, a third of the world's population, have no access to modern energy services. World population is expected to double by the end of the $21^{\text {st }}$ century. A key issue to improve the standard of living of the poor is to make clean energy available to them at prices they can afford. Energy affects all aspects of modern life (WEC, 1993). There is a strong positive correlation between energy use per capita in a country and issues that we value highly such as productivity per capita in the country and life expectancy.

The World Energy Council has presented several scenarios for meeting the future energy requirements with varying emphasis on economic growth, technological progress, environmental protection and international equity. During 1990-2050, the primary energy consumption is expected to increase by $50 \%$ according to the most environmentally conscious scenario and by $275 \%$ according to the highest growth rate scenario. In the environmental scenario, the carbon emissions are expected to decrease slightly from 1990 levels, whereas the high growth-rate scenario leads to a doubling of the carbon emissions (Nakicenovic et al., 1998). The scarcity of energy resources forecasted in the 1970s has not occurred so far. Economic development in the new century will not be constrained by geological resources. Environmental concerns, financing, and technological constrains appear more likely sources of future limits (Fridleifsson, 2000).

In all scenarios, the peak of the fossil fuel era has already passed. Oil and gas are expected to continue to be important sources of energy (Nakicenovic et al., 1998). The share of renewable energy sources is expected to increase very significantly (to $30-80 \%$ in 2100). Hydropower and traditional biomass are already important factors in the world's energy mix, contributing about $18 \%$ of the total world energy requirements, whereas the "new" renewables contribute only about $2 \%$ of the present world primary energy use. The potentially largest single contributor of the "new" renewables, namely solar energy for electricity production, is still not commercially competitive with conventional energy sources. "Modern" biomass, wind and geothermal energy are commercially competitive and are making a relatively fast progress. 
It is clear that no single energy source is going to take over from the polluting fossil fuels in the new century. The integration of local energy sources in individual countries and regions into national/regional systems that make use of the best local and imported energy is important if we are to find solutions to regional and global energy problems. Proponents for the renewable energy sources need to work together in the world energy market which is very conservative.

The present paper describes the status of geothermal energy development in the world. It furthermore compares the status of the renewable energy resources, namely hydropower, biomass, geothermal, wind, solar and tidal energy. The comparison is mainly based on data presented in the recently published World Energy Assessment report (WEA, 2000), prepared by UNDP, UN-DESA and the World Energy Council.

\section{HOT SPRINGS USED THROUGH THE CENTURIES}

People have used hot springs for bathing and washing of clothes since the dawn of civilisation in many parts of the world. Vestiges of Japanese culture have been unearthed near theYuda hot spring (Iwate Prefecture) dating from the pre-pottery period before 11,000 B.C. (Sekioka, 1999), and at the Kawazu hot spring (Nagasaki Prefecture), dating from the Jomon period (11,000-300 B.C.). There are over two thousand years old written records of geothermal usage in China. Public baths became common at hot spring localities in the Roman empire around two thousand years ago extending from England to Tunisia and Syria. Pipes were used for hot and cold water in the old bathing installations in China and Europe, but pipe systems did not become common until in the early $20^{\text {th }}$ century. Space heating with hot air was known during Roman times, but radiators for space heating first became common a century ago. Minerals have been extracted from the geothermal water since Etruscan times in Italy.

The main use of hot springs through the centuries has, however, been for bathing and washing. The common people took baths in natural pools which are remembered in legends only. The healing nature of the hot springs has been recognised in all continents since ancient times. An excellent book was recently published with historical records and stories of geothermal utilisation from all over the world (Cataldi et al., 1999).

\section{PRESENT USE AND POTENTIAL OF GEOTHERMAL}

It was first in the 20th century that geothermal energy was harnessed on a large scale for space heating, industry, and electricity generation. Prince Piero Ginori Conti initiated electric power generation with geothermal steam at Larderello, Tuscany, in 1904. The first large scale municipal district heating service started in Iceland in 1930. Geothermal energy has been produced commercially for over eighty years, and for four decades on the scale of hundreds of MW both for electricity generation and direct use. The utilisation has increased rapidly during the last three decades. In 2000, geothermal resources have been identified in over 80 countries and there are quantified records of geothermal utilisation in 58 countries in the world.

Table 1: Electricity generation and direct use of geothermal energy in 2000 Based on Huttrer (2001), and Lund and Freeston (2001)

(Asia direct use value modified to include baths in Japan)

\begin{tabular}{|l|c|c|c|c|r|r|}
\hline & \multicolumn{3}{|c|}{ Electricity generation } & \multicolumn{3}{c|}{ Direct Use } \\
\cline { 2 - 7 } & $\begin{array}{l}\text { Installed capacity } \\
\text { MWe }\end{array}$ & \multicolumn{2}{|c|}{ Total production } & \multicolumn{2}{c|}{ Installed capacity } & \multicolumn{2}{c|}{ Total production } \\
GWh/a & \% & MWt & GWh/a & \% \\
\hline Africa & 54 & 397 & 1 & 125 & 504 & 1 \\
America & 3390 & 23342 & 47 & 4355 & 7270 & 14 \\
Asia & 3095 & 17510 & 35 & 4608 & 24235 & 46 \\
Europe & 998 & 5745 & 12 & 5714 & 18905 & 35 \\
Oceania & 437 & 2269 & 5 & 342 & 2065 & 4 \\
\hline Total & $\mathbf{7 9 7 4}$ & $\mathbf{4 9 2 6 3}$ & $\mathbf{1 0 0}$ & $\mathbf{1 5 1 4 4}$ & $\mathbf{5 2 9 7 9}$ & $\mathbf{1 0 0}$ \\
\hline
\end{tabular}

The worldwide use of geothermal energy amounts to about $49 \mathrm{TWh} / \mathrm{a}$ of electricity and 53 TWh/a for direct use (Table 1). A new estimate of the geothermal potential of the world (Stefansson, 1998), gives the total potential for the resources suitable for electricity generation (resource temperature in excess of $150^{\circ} \mathrm{C}$ ) as $11,000 \pm 1,300 \mathrm{TWh} / \mathrm{a}$, and the total potential resources for direct 
use (resource temperature lower than $150^{\circ} \mathrm{C}$ ) in excess of $1400 \mathrm{EJ} / \mathrm{a}(390,000 \mathrm{TWh} / \mathrm{a}$ heat). These figures for the potential cover both known and unidentified resources. Stefansson (1998) estimates the identified geothermal resources to be $2000 \pm 140 \mathrm{TWh} / \mathrm{a}$ for electricity generation, and in excess of $7000 \mathrm{TWh} / \mathrm{a}$ heat for direct use. An earlier version of this estimate is also found in Bjornsson et al. (1998). It is clear that the present use of geothermal energy (49 TWh/a for electricity and $53 \mathrm{TWh} / \mathrm{a}$ for direct use) is a very small fraction of the identified geothermal potential. There is certainly space for an accelerated use of geothermal energy both for electricity generation and direct use in the near future. With both ample resources and a relatively mature technology at hand, the question of future development of geothermal utilisation boils down to economic and political competitiveness with other energy sources on the market in the different countries.

\section{ELECTRICITY PRODUCTION}

Electricity is produced with geothermal steam in 21 countries spread over all continents (Table 1). The top ten countries in 1999 were (MWe in brackets): USA (2228), Philippines (1909), Italy (785), Mexico (755), Indonesia (590), Japan (547), New Zealand (437), Iceland (170), El Salvador (161), and Costa Rica (143). The most progressive country at present, the Philippines, plans to add 526 MWe to the installed capacity during 2002-2008. About $22 \%$ of the electricity in the Philippines is generated with geothermal steam. Other countries generating $10-20 \%$ of their electricity with geothermal at present are Costa Rica, El Salvador, Iceland and Nicaragua. Two new countries have recently commissioned their first geothermal power stations, Ethiopia (9 MWe) and Guatemala (33 $\mathrm{MWe}$ ). Table 3 (from Huttrer, 2001) shows the installed capacity, the generated electricity, and the percentage of the national electrical capacity and energy production of the 21 countries respectively in the year 1999. The electric generation cost is variable, but commonly around $4 \mathrm{US}$ cents/kWh. The lowest cost is obtained with co-generation of electricity (2 UScents/kWh) and hot water for district heating (0.5 UScents/kWh) in two high temperature fields in Iceland.

Table 2: Installed geothermal generating capacities (from Huttrer, 2001)

\begin{tabular}{lcccc}
\hline Country & $\begin{array}{c}\text { Installed } \\
\text { MWe }\end{array}$ & $\begin{array}{c}\text { GWh } \\
\text { generated }\end{array}$ & $\begin{array}{c}\text { \% of } \\
\text { national capacity }\end{array}$ & $\begin{array}{c}\text { \% of } \\
\text { national energy }\end{array}$ \\
\hline Australia & 0.17 & 0.9 & $\mathrm{n} / \mathrm{a}$ & $\mathrm{n} / \mathrm{a}$ \\
China & 29.17 & 100 & $\mathrm{n} / \mathrm{a}$ & $\mathrm{n} / \mathrm{a}$ \\
Costa Rica & 142.5 & 592 & 7.77 & 10.21 \\
El Salvador & 161 & 800 & 15.39 & 20 \\
Ethiopia & 8.52 & 30.05 & 1.93 & 1.85 \\
France & 4.2 & $24.6 *$ & $\mathrm{n} / \mathrm{a}$ & 2 \\
Guatemala & 33.4 & 215.9 & 3.68 & 3.69 \\
Iceland & 170 & 1138 & 13.04 & 14.73 \\
Indonesia & 589.5 & 4575 & 3.04 & 5.12 \\
Italy & 785 & 4403 & 1.03 & 1.68 \\
Japan & 546.9 & 3532 & 0.23 & 0.36 \\
Kenya & 45 & 366.47 & 5.29 & 8.41 \\
Mexico & 755 & 5681 & 2.11 & 3.16 \\
New Zealand & 437 & 2268 & 5.11 & 6.08 \\
Nicaragua & 70 & 583 & 16.99 & 17.22 \\
Philippines & 1909 & 9181 & $\mathrm{n} / \mathrm{a}$ & 21.52 \\
Portugal & 16 & $94 *$ & 0.21 & $\mathrm{n} / \mathrm{a}$ \\
Russia & 23 & 85 & 0.01 & 0.01 \\
Thailand & 0.3 & $1.8 *$ & $\mathrm{n} / \mathrm{a}$ & $\mathrm{n} / \mathrm{a}$ \\
Turkey & 20.4 & $119.73 *$ & $\mathrm{n} / \mathrm{a}$ & $\mathrm{n} / \mathrm{a}$ \\
USA & 2228 & 15,470 & 0.25 & 0.4 \\
\hline
\end{tabular}

Totals

$7974.06 \quad 49,261.45$

* = These figures are based on an estimated $67 \%$ utilization factor. The actual GWh were not included in the Country Update Papers.

\section{DIRECT USE OF GEOTHERMAL ENERGY}

Direct application of geothermal energy can involve a wide variety of end uses, such as space heating and cooling, industry, greenhouses, fish farming, and health spas. It uses mostly existing 
technology and straight forward engineering. The technology, reliability, economics, and environmental acceptability of direct use of geothermal energy has been demonstrated throughout the world. The main types of direct use (Lund and Freeston, 2001) are bathing/swimming/balneology (42\%), space heating (35\%, thereof $12 \%$ with geothermal heat pumps), greenhouses ( $9 \%)$, fish farming $(6 \%)$, and industry (6\%).

Direct application can use both high- and low-temperature geothermal resources and is therefore much more widespread in the world than electricity production. Direct application is, however, more site specific for the market, as steam and hot water is rarely transported long distances from the geothermal site. The longest geothermal hot water pipeline in the world is $63 \mathrm{~km}$, in Iceland. The production cost/kWh for direct utilization is highly variable, but commonly under $2 \mathrm{UScents} / \mathrm{kWh}$.

Table 3 shows the installed capacity and produced energy in the top fifteen direct use countries. The table is based on data from Lund and Freeston (2001).

Table 3: World's top countries using geothermal in direct uses

\begin{tabular}{|lcc|}
\hline Installed & $\begin{array}{c}\text { Production } \\
\text { MWt }\end{array}$ & $\begin{array}{c}\text { GWh/a } \\
\text { China }\end{array}$ \\
Japan & 1167 & 7482 \\
USA & 3766 & 5640 \\
Iceland & 1469 & 5603 \\
Turkey & 820 & 4377 \\
New Zealand & 308 & 1967 \\
Georgia & 250 & 1752 \\
Russia & 308 & 1707 \\
France & 326 & 1360 \\
Sweden & 377 & 1147 \\
Hungary & 473 & 1135 \\
Mexico & 164 & 1089 \\
Italy & 326 & 1048 \\
Romania & 152 & 797 \\
Switzerland & 547 & 663 \\
\hline
\end{tabular}

China has geothermal water in almost every province. The direct utilisation is expanding at a rate of about $10 \%$ per year, mainly in the space heating (replacing coal), bathing, and fish farming sectors. Japan is also blessed with very extensive geothermal resources which so far have mainly $(80 \%)$ been used for bathing, recreation and tourism as well as for electricity production. This has improved the quality of life of people significantly, but only a fraction of the available geothermal energy is used so far. Turkey has shot up the list of top direct use geothermal countries in recent years. Mexico is the first country extending into the tropics to report significant direct use of geothermal. Switzerland and Sweden have recently joined the top league through extensive use of ground source heat pumps.

\section{HEAT PUMP APPLICATIONS}

Geothermal energy has until recently had a considerable economic potential only in areas where thermal water or steam is found concentrated at depths less than $3 \mathrm{~km}$ in restricted volumes, analogous to oil in commercial oil reservoirs. This has recently changed with developments in the application of ground source heat pumps using the earth as a heat source for heating or as a heat sink for cooling, depending on the season. This has made it possible for all countries to use the heat of the earth for heating and/or cooling, as appropriate. It should be stressed that the heat pumps can be used basically everywhere.

During the last decade, a number of countries have encouraged individual house owners to install ground source heat pumps to heat their houses in the winter and (as needed) cool them in the summer. Financial incentive schemes have been set up, commonly funded by the governments and electric utilities, as the heat pumps reduce the need for peak power and thus replace new electric generating capacity. USA leads the way with about 400,000 heat pump units (about 4,800 MWt) and energy production of 3,300 GWh/y in 1999 (Lund and Boyd, 2000). The annual increase is about 10\%. Other leading countries are Switzerland, Sweden, Germany, Austria, and Canada. 
Switzerland, a country not known for hot springs or geysers, gives an example of the impact this can have on the geothermal applications in what previously would have been called nongeothermal countries. The energy extracted out of the ground with heat pumps in Switzerland (Rybach et al., 2000) amounts to $434 \mathrm{GWh} / \mathrm{y}$. The annual growth rate is $12 \%$.

Switzerland has a population of about 7 million people. If the same level of utilisation would materialise in Japan (130 million people), the utilisation of geothermal through the heat pumps alone would amount to some $8 \mathrm{TWh} / \mathrm{y}$. This is a very respectable value in comparison with the total direct use of geothermal in Japan in 1999 without baths of 1.5 TWh/y (Sekioka and Yoshii, 2000) and the total use in 1996 including the baths of 7.5 TWh/y (Uchida, 1997).

\section{GEOTHERMAL FOR THE BENEFIT OF THE PEOPLE}

People in at least 64 countries around the world are enjoying the use of geothermal resources in variable forms. The scale of use is, however, very variable. The country with the most extensive use of geothermal energy is Iceland which obtains $50 \%$ of the total primary energy use from geothermal, the remainder comes from hydropower $18 \%$, oil $30 \%$ and coal $2 \%$. About $68 \%$ of the primary energy of Iceland are thus produced by renewable energy sources. The average figure for the countries of the European Union (EU) is slightly over $5 \%$. The only EU countries with over $8 \%$ of their gross inland consumption coming from renewables are Austria and Sweden with about $22 \%$ as well as Portugal and Finland with about 19\%.

Geothermal energy provides $86 \%$ of all space heating in Iceland and about $16 \%$ of the electricity generation (the remainder is hydropower). Geothermal energy is also used for greenhouses, industry, fish farming, snow melting and bathing (Ragnarsson, 2000). It is surprising to many that in a country with an average temperature of $-1^{\circ} \mathrm{C}$ in January and $12^{\circ} \mathrm{C}$ in July, swimming in outdoor pools is very popular around the year. In the capital Reykjavik (population 110,000) there were 1.7 million visitors to the six public swimming pools in 1999. In the largest outdoor pool there were on average 36,000 visitors in January and 57,000 visitors in July in the years 1995-1999. Geothermal energy has not only improved the economy and the environment in Iceland but also improved the quality of life of the people significantly. Polluting fossil fuels (which have to be imported) are only used in Iceland in the transport sector (cars, ships and aeroplanes).

In Iceland, the geothermal water is commonly piped $10-20 \mathrm{~km}$ from the geothermal fields to the towns. Transmission pipelines are mostly of steel insulated by rock wool (surface pipes) or polyurethane (subsurface). In recent years, several small villages and farming communities have successfully used plastic pipes (polybutylene) with polyurethane insulation as transmission pipes. The temperature drop is insignificant in large diameter pipes with high flow rate, exemplified by $1^{\circ} \mathrm{C}$ drop in a $27 \mathrm{~km}$ pipeline with $800 \mathrm{~mm}$ diameter and $5^{\circ} \mathrm{C}$ in a $11 \mathrm{~km}$ pipeline with $175 \mathrm{~mm}$ diameter. The temperature drop in a $19 \mathrm{~km}$ plastic pipeline with $110 \mathrm{~mm}$ diameter is $15^{\circ} \mathrm{C}$.

In addition to China (with an annual expansion of 10\%), recent examples of a high growth rate in the direct use of geothermal are found in countries such as Turkey and Tunisia. In Turkey, the installed capacity for space heating (residences and greenhouses) grew from $160 \mathrm{MWt}$ in 1994 to 490 $\mathrm{MWt}$ in 1999. This replaced mostly coal heating. Additional $327 \mathrm{MWt}$ are used for balneological purposes in the 194 spas in the country. The installed capacity for space heating is expected to be 3,500 MWt in year 2010 (Batik et al., 2000). In Tunisia, geothermally heated greenhouses have expanded from 10,000 $\mathrm{m}^{2}$ in 1990 to 955,000 $\mathrm{m}^{2}$ in 1999 (Said, 1997; Sbita (2000) personal communication). The greenhouses in Tunisia do, in fact, replace cooling towers five months per year to cool irrigation water from deep wells from 75 to $30^{\circ} \mathrm{C}$ in oases in the Sahara desert. The geothermal heat is therefore a byproduct of the irrigation water. The main products in the greenhouses are tomatoes and melons for export to Europe. The greenhouses create new jobs in the oases.

\section{ENVIRONMENTAL ISSUES}

Geothermal fluids contain a variable quantity of gas, largely nitrogen and carbon dioxide with some hydrogen sulphide and smaller proportions of ammonia, mercury, radon and boron. The amounts depend on the geological conditions of different fields. Most of the chemicals is concentrated in the disposal water which is routinely reinjected into drillholes and thus not released into the environment. The concentration of the gases are usually not harmful, and the removal of e.g. hydrogen sulphide from geothermal steam is a routine matter in geothermal power stations where the gas content is high. 
The range in $\mathrm{CO}_{2}$ emissions from high-temperature geothermal fields used for electricity production in the world is $13-380 \mathrm{~g} / \mathrm{kWh}$, whereas the $\mathrm{CO}_{2}$ emissions are $453 \mathrm{~g} / \mathrm{kWh}$ for natural gas, $906 \mathrm{~g} / \mathrm{kWh}$ for oil and $1042 \mathrm{~g} / \mathrm{kWh}$ for coal. Sulphur emissions are also significantly less for geothermal than fossil fuel electric power stations.

The gas emissions from low-temperature geothermal resources are normally only a fraction of the emissions from the high-temperature fields used for electricity production. The gas content of lowtemperature water is in many cases minute, like in Reykjavik (Iceland), where the $\mathrm{CO}_{2}$ content is lower than that of the cold groundwater. In sedimentary basins, such as the Paris basin, the gas content may be too high to be released. In such cases the geothermal fluid is kept at pressure within a closed circuit (the geothermal doublet) and reinjected into the reservoir without any de-gassing taking place. Conventional geothermal schemes in sedimentary basins commonly produce brines which are generally reinjected into the reservoir and thus never released into the environment $\left(\mathrm{CO}_{2}\right.$ emission zero).

Thanks to geothermal district heating, Reykjavik (Iceland) is one of the cleanest capitals in the world. There is no smoke from chimneys. Heating with polluting fossil fuels has been eliminated. Geothermal utilization has reduced $\mathrm{CO}_{2}$ emissions in Iceland by 1.9 million tonnes/a compared to the burning of fossil fuels. The total release of $\mathrm{CO}_{2}$ in Iceland is 2.2 million tonnes/a. The reduction has significantly improved Iceland's position globally in this respect. Many countries could reduce their emissions significantly through the use of geothermal energy.

\section{COMPARISON OF GEOTHERMAL WITH OTHER RENEWABLES}

The World Energy Assessment report, prepared by UNDP, UN-DESA and the World Energy Council, has recently been published. It gives a very valuable and comprehensive description of the status of the world's energy sources at the turn of the millennium. The report is published as an input to the session on "energy and sustainable development" of the United Nations Commission on Sustainable Development that will take place in April 2001. Chapter 7 of this voluminous report deals with the renewable energy technologies and includes a highly interesting table entitled "Current status and potential future costs of renewable energy technologies" (Turkenburg, 2000). The data presented here in Tables 4, 5 and 6 is extracted from Table 7.25 of the World Energy Assessment report.

Table 4: Status of electricity production from renewables

(Data source: World Energy Assessment Report (WEA, 2000), modified from Table 7.25 of Turkenburg, 2000)

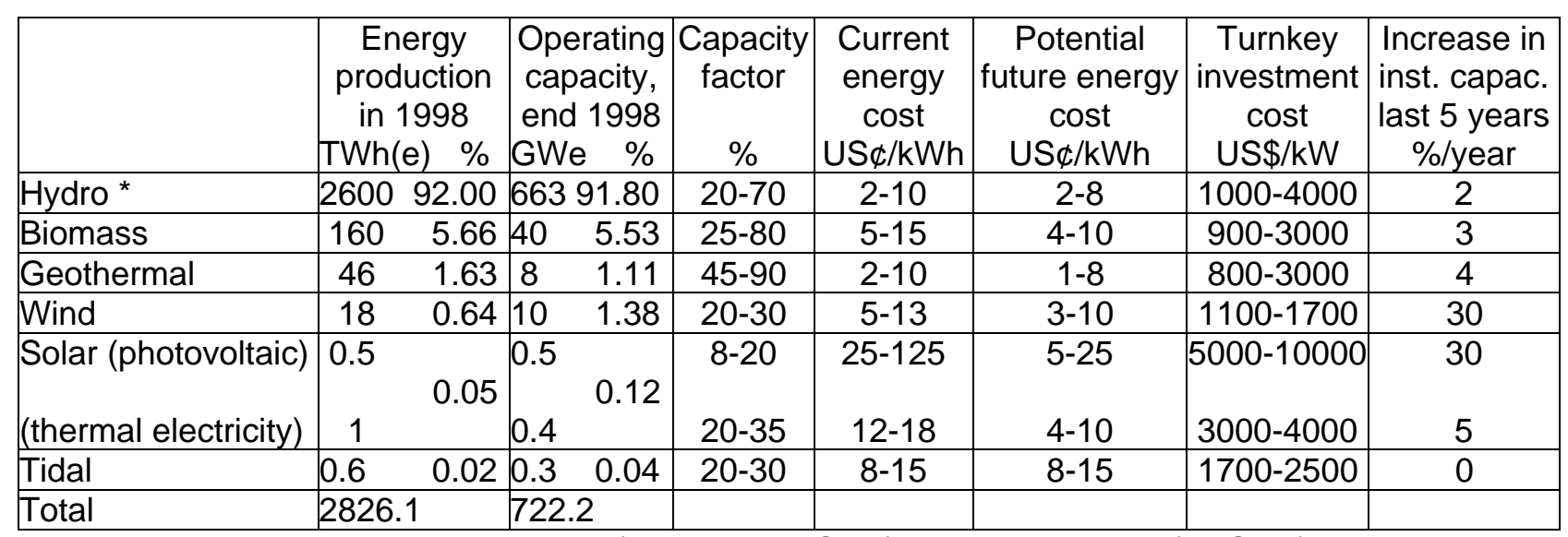

* Large hydro stations produce 2510 TWh (capacity $640 \mathrm{GWe}$ ) and small 90 TWh (23 GWe).

Table 4 shows the status of electricity production from renewables. The total electricity production from renewables in 1998 was 2826 TWh. By far the largest contribution (92\%) came from hydropower, but $5.7 \%$ from biomass, $1.6 \%$ from geothermal, and $0.6 \%$ from wind. The electricity production by solar energy constituted only $0.05 \%$ and from tidal energy $0.02 \%$. The current energy cost is lowest for hydropower and geothermal, followed by biomass and wind. Solar photovoltaic electricity is by far the most expensive, but significant cost reductions are expected in the future. The annual \% increase in installed capacity during the last 5 years is $2-4 \%$ for hydro, biomass and geothermal, but reported $30 \%$ for wind and solar photovoltaic.

Table 5: Electricity from four renewable energy resources in 1998 (compiled from data in WEA, 2000) 


\begin{tabular}{|l|c|c|c|c|}
\cline { 2 - 5 } \multicolumn{1}{c|}{} & GWe & \% & TWh/y & \% \\
\hline Geothermal & 8 & 41.7 & 46 & 69.6 \\
Wind & 10 & 52.1 & 18 & 27.2 \\
Solar & 0.9 & 4.7 & 1.5 & 2.3 \\
Tidal & 0.3 & 1.5 & 0.6 & 0.9 \\
\hline Total & 19.2 & 100 & 66.1 & 100 \\
\hline
\end{tabular}

The capacity factor is highly variable for the different sources. Table 5 shows the operating capacity and the electricity production in 1998 for four "new and renewable" energy sources, namely geothermal, wind, solar and tidal energy. The data for the Table is compiled from Turkenburg (2000). It is apparent that in 1998, wind energy was in the leading position with regard to operating capacity (52.1\%) followed by geothermal (41.7\%). Geothermal was, however, the leading electricity producer with $69.6 \%$ of the total electricity production of the four, followed by wind energy with $27.2 \%$ of the production. The relatively high share in the electricity production reflects the reliability of geothermal plants which commonly have a capacity factor of $70-90 \%$. Geothermal energy is independent of weather contrary to solar, wind, or hydro applications. It has an inherent storage capability and can be used both for base load and peak power plants. However, in most cases, it is more economical to run the geothermal plants as base load suppliers.

Table 6: Status of direct heat production from renewables

(Data source: World Energy Assessment Report (WEA, 2000), modified from Table 7.25 of Turkenburg, 2000)

\begin{tabular}{|l|c|c|c|c|c|c|c|}
\hline & $\begin{array}{c}\text { Energy } \\
\text { production } \\
\text { in 1998 } \\
\text { TWh th }\end{array}$ & $\begin{array}{c}\text { Operating } \\
\text { capacity } \\
\text { end 1998 } \\
\text { GWth }\end{array}$ & $\begin{array}{c}\text { Capacity } \\
\text { factor }\end{array}$ & $\begin{array}{c}\text { Current } \\
\text { energy cost }\end{array}$ & $\begin{array}{c}\text { Potential } \\
\text { future } \\
\text { energy cost } \\
\text { US } \$ / k W h W\end{array}$ & $\begin{array}{c}\text { Turnkey } \\
\text { investment } \\
\text { cost } \\
\text { US } \$ / k W\end{array}$ & $\begin{array}{c}\text { Increase in } \\
\text { inst. capac. } \\
\text { last 5years } \\
\% / y e a r\end{array}$ \\
\hline Biomass & $>700$ & $>200$ & $25-80$ & $1-5$ & $1-5$ & $250-750$ & 3 \\
\hline Geothermal & 40 & 11 & $20-70$ & $0.5-5$ & $0.5-5$ & $200-2000$ & 6 \\
\hline $\begin{array}{l}\text { Solar heat } \\
\text { Low temp. }\end{array}$ & 14 & 18 & $8-20$ & $3-20$ & $2-10$ & $500-1700$ & 8 \\
\hline
\end{tabular}

* Turkenburg's table 7.25 also shows ethanol under biomass, with operating capacity (end 1998) 18 billion litres, energy production of $420 \mathrm{PJ}$, current energy cost 8-25 $\$ / \mathrm{GJ}$ and future potential energy cost of $6-10 \$ / G J$.

Table 6 shows the status of direct heat production from renewables. Biomass constitutes at least $93 \%$ of the total, geothermal $5 \%$ and solar heating $2 \%$. The biomass shown here is, of course, only a fraction of the total use of biomass in the world, as fuel wood etc. is not included. The biomass energy shown here is heat embodied in steam (or hot water in district heating), often produced by combined heat and power production using forest residues, black liquor, or bagasse (Turkenberg, 2000). Each of these energy sources are site specific and have their respective restraints. As regards geothermal energy, it is widely used for municipal district heating systems, with the largest systems in Iceland, France, China and Turkey. Space heating of individual houses is also common, not least in the USA.

Heat production from renewables is competitive with conventional energy sources. The current cost of direct heat from biomass is 1-5 UScents/kWh, geothermal 0.5-5 UScents/kWh, and solar heating 3-20 UScents/kWh.

\section{DISCUSSION}

Geothermal energy has been produced commercially for eighty years, and on the scale of hundreds of MW for four decades, both for electricity generation and direct use. The utilisation has increased rapidly during the last three decades. In 2000, there are records of geothermal utilisation in 58 countries in the world. The electricity generated is about $49 \mathrm{TWh} / \mathrm{a}$, and the direct use amounts to about $53 \mathrm{TWh} / \mathrm{a}$.

Based on the country reports at the World Geothermal Congress 2000, Huttrer (2001) expects the world electrical installed capacity to have grown by $43 \%$ in 2005 . Assuming a continuing growth of $20 \%$ per five years (which is the average growth during 1980-2000), the electrical production may reach about 80 TWh in 2010 and 120 TWh in 2010. Assuming the worldwide direct use growth of $44 \%$ during 1995-2000 reported by Lund and Freeston (2001) to continue, the direct use energy production may be about 100 TWh in 2010 and 200 TWh in 2020. Recent developments in the application of the 
ground source heat pump opens a new dimension in using the earth's heat, as heat pumps can be used basically everywhere. This suggests that the growth rate for direct use will continue to be high.

Geothermal energy, with its proven technology and abundant resources, can make a significant contribution towards reducing the emission of greenhouse gases worldwide. It is necessary that governments implement a legal and institutional framework and fiscal instruments allowing geothermal resources to compete with conventional energy systems.

International forecasts expect the share of renewable energy sources in the world energy mix to increase very significantly in the new century (to $30-80 \%$ in 2100). How large the share of geothermal energy will be in the world energy at the end of the new century is much dependant on the actions of the geothermal community and the countries leading geothermal development.

\section{ACKNOWLEDGEMENTS}

The author would like to thank Valgardur Stefansson of Orkustofnun, the National Energy Authority of Iceland, for reviewing the manuscript and many helpful comments.

\section{REFERENCES}

1. Batik, H., Kocak, A., Akkus, I., Simsek.S., Mertoglu, O., Dokuz, I., and Bakir., N. (2000). Geothermal energy utilisation development in Turkey. World Geothermal Congress, WGC2000,CD-ROM, p.85-91.

2. Björnsson, J., Fridleifsson,I.B., Helgason, Th., Jonatansson, H. Mariusson, J.M., Palmason. G., Stefansson, V., and Thorsteinsson, L. (1998). The potential role of geothermal energy and hydro power in the world energy scenario in year 2020. Proceedings of the $17^{\text {th }}$ WEC Congress, Houston, Texas.

3. Cataldi, R, Hodgson, S.F., and Lund, J.W. (1999). Stories from a Heated Earth. Geothermal Resources Council and International Geothermal Association, 569 pp.

4. Fridleifsson, I.B. (2000). Energy requirements for the next millennium. Conference proceedings "On the Threshold: The United Nations and Global Governance in the New Millennium". United Nations University, Tokyo, January 2000.

5. Huttrer, G.W. (2001). The status of world geothermal power generation 1995-2000. Geothermics 30, 1-27.

6. Lund, J.W. and Boyd, T.L. (2000). Geothermal direct-use in the United States, Update 19951999. WGC2000,CD-ROM, p.297-305.

7. Lund, J.W. and Freeston, D.H. (2001). World-wide direct uses of geothermal energy 2000. Geothermics 30, 29-68.

8. Nakicenovic, N., A. Grübler, and A. McDonald, (editors) 1998. Global Energy Perspectives, Cambridge Univ. Press, 299 p.

9. Ragnarsson, A., (2000). Geothermal Development in Iceland 1995-1999. WGC2000,CD-ROM, p. 363-375.

10. Rybach, L., Brunner, M., and Gorhan, H. (2000). Swiss geothermal energy update 1995-2000. WGC2000,CD-ROM, p. 413-426.

11. Said, M. (1997). Geothermal utilisation for heating, irrigation and soil disinfection in greenhouses in Tunisia. United Nations University Geothermal Training Programme, Reykjavik, Report 1997-13, 311-338.

12. Sekioka, M. (1999). Japanese geothermal waters through history. In: Cataldi, R, Hodgson, S.F., and Lund, J.W.(1999). Stories from a Heated Earth, pp. 392-405. Geothermal Resources Council and International Geothermal Association,

13. Sekioka, M. and Yoshii, M. (2000). Country update report of geothermal direct use in Japan. WGC2000,CD-ROM, p. 433-437.

14. Stefansson, V. (1998). Estimate of the world geothermal potential. In: "Geothermal Training in Iceland $20^{\text {th }}$ Anniversary Workshop". United Nations University Geothermal Training Programme, Reykjavik. p.111-120.

15. Turkenburg, W.C. (2000). Current status and potential future costs of renewable energy technologies, Table 7.25, World Energy Assessment report, prepared by UNDP, UN-DESA and the World Energy Council. United Nations, New York. 
16. Uchida, T. (1997). Lecture notes on direct use of geothermal resources in Japan. United Nations University Geothermal Training Programme, Reykjavik. 20 p.

17. WEA (2000). World Energy Assessment report, prepared by UNDP, UN-DESA and the World Energy Council. United Nations, New York.

18. WEC (1993). Energy for Tomorrow's World, St. Martin's Press, USA, pp. 320. 